\title{
Mehmed Uzun as a Representative of Modern Kurdish Narrative
}

\author{
Chiad Abdulkarim ${ }^{1}$, Ismael Saeed ${ }^{2}$ \\ ${ }^{1}$ Dept. of English Language, Faculty of Humanities, University of Zakho, Kurdistan Region - Iraq. chiad.abdulkarim@uoz.edu.krd \\ ${ }^{2}$ Dept. of English Language, College of Language, Salahaddin University, Kurdistan Region - Iraq. ismaelsaeed1961@ hotmail.com
}

Received: 07. 2019 / Accepted: 09. 2019 / Published: 09. 2019 https://doi.org/10.26436/hjuoz.2019.7.3.523

\begin{abstract}
:
This article is dedicated to the analysis of Mehmed Uzun's initial Two novels, Tu (1985) and Mirina Kalekî Rind (1987). It focuses on Mehmed Uzun as a representative of modern Kurdish narrative. When it comes to the concepts of identity distortion in characters and their complicated state of mind, his novels can be a relevant subject matter for interpretation.

In light of Mikhail Bakhtin's theory of polyphony and the scholars who worked in his circle, this article explores the polyphonic aspects of Mehmed Uzun's two initial novels. Through novelistic discourse analysis, it becomes apparent that the characters suffer from the dormant identity, which is locally given to them in Uzun's diasporic fiction.

Next, the discussion gives further details regarding polyphony and how problematic polyphony can be found in the novels mentioned above. Finally, this article sheds light on the notion of identity formation in the fictional novel and its relationship with the real world during the time the novels were written. It concludes that the entire representation of characters and settings in his novels leads to the production of a realistic novel with the consistent discourse that can be considered an objective view of a specific time in history which is undermined.
\end{abstract}

KEYWORD: Polyphony, Mehmed Uzun, Diasporic fiction, Modern Kurdish novel, Dormant identity

\section{Introduction}

One of the dominant aspects of the Kurdish literature, specifically in novels, is its concern with socio-political issues presented through nostalgia and flashbacks. In some cases, the main character's mission in the novel is to reconnect to their past. Next, the protagonist goes through flashbacks and recounts his or her past life in the hope that she or he can bring forward such moments so that the reader could get engaged with the complexities of the life which the character has been through. The flashback is often about a little home that represents the notion of the homeland; in most cases, a safe and stable location for the character. The character usually longs for that home, takes the readers back to his childhood place in the novel and more importantly, as a child that has no clear definition of borders and statehood, that little home makes more sense than being an adult with a clear definition of statehood sovereignty. This means that the character is having troubles in identifying himself within the environment he is entrapped in and is incapable of easily coping with his status quo.

This article is an attempt to explore specific elements of Mehmed Uzun's initial fictional works and how they contribute to the realm of Kurdish novel. The main reason behind this study is to bring to light the artistic elements and otherness that exists in Uzun's novels, which has been depreciated by the scholars since his novels were published in Kurdish. This makes them inaccessible to a wide range of readerships as well as the specific academic journals and scholars who publish in the English language. It was also noted through this study that very few sources are available in the English language that directly deals with Uzun's novel. That is why the research finds it necessary to give an attempt in analyzing the initial novels in the light of the literary approaches such as polyphony, close reading, and new historicism. The reason behind choosing an eclectic approach is due to the findings of this article, which states that genuine polyphony can only be achieved when the text is disconnected from its author. This means the application of other literary approaches is inappropriate. As a result, this article has considered more than one literary approach to proving that other types of polyphony, such as problematic or partial polyphony, can be achieved when other approaches are applied that has been established in the second half of the 20th century.

\subsection{Diasporic Fiction: Unusual route to connect to mother tongue}

Although previous attempts were made by few Kurdish writers to publish in their mother tongue in Turkey, it was not until the end of the twentieth century that only a few books, written in Kurdish, made their way into publication. The rest of the writers were not only denied the rights of publication but in most cases ended up being trialed and imprisoned. Mehmed Uzun took an unusual route in publishing his novels; he migrated to Sweden, and there he continued writing his works and started publishing his writings, mainly novels. He was the first writer from Turkey to publish novels in his mother language. Initially, his novel entitled Tu was published in 1985, and it was available in the Kurdistan region of Iraq in the same year. Thus, Uzun is considered as the first Kurdish novelist from Turkey who published in Kurmanji Kurdish. However, other Kurdish novelists were writing in Kurdish from other countries. A closer look at several of the utterances in Uzun's novel Tu can lead readers to the essence of the voices in this novel. It is important to note that that Uzun is considered the first Kurdish novelist to have published novels prolifically in the Kurdish language from Turkey, that is why this article is limited to the consideration of classifying voices in Uzun's initial novels only.

Mehmed Uzun's novel Tu combines multiple voices that represent different social groups, and all contribute to the production of what feels like an unfinished novel. These voices are presented in the form of a set of utterances through $\mathrm{Tu}$ and include oral, factual, religious, and symbolic references. This generic combination is by itself a characteristic of modern 
realism, particularly for minorities whose cultural elements have been dominated by others in power and were subject to assimilation. Therefore, novelists like Mehmed Uzun, who mostly wrote and lived in exile, embedded more than one genre into the discourse of their novels, such as anecdotes, poetry, and even folktales in order to preserve the sense of "otherness" banned by the government. In his novel, Uzun has reconstructed individual voices to preserve aspects of the Kurdish society such as language and literature.

Although Tu was only introduced into Kurdish literature at the second half of 20th century, and very few Kurdish novels had been previously published, for Uzun, the Kurdish novel was the most appropriate literary genre because it enabled him to express a diversity of voices grouped into a series of utterances in which he incorporated into his novel. The novel takes place in a prison in the ancient city of Diyarbakir. It is the ideal setting to recreate the struggles experienced by the Kurdish prisoners, and it allows the various characters' voices to resonate together.

The use of voices in the novel is a literary technique deployed to reflect the complicated aspects of the characters' daily lives. Within the text, however, Uzun borrows from poems, anecdotes, and stories alluding some of the cultural aspects that are being lost through the passing of generations. Nevertheless, this relationship between the text and the context leads to the question of whether real-world factors - rather than literary motivesunderlie Uzun's use of voices in the novel.

Also, this study focuses on the Kurdish cultural elements in Uzun's narrative style that made this novel possible. This article will analyze this style and respond to the following questions: Did the author intentionally reconstruct individual voices in his novel, or are they a matter of self-reference? Is his discourse subjective or objective? Does Uzun's Tu express social life, or is it a medium of his interpretative reading of the time the novel was written? Based on the text and the context of the novel, this article responds to the above questions. It highlights the style of Uzun's discourse in creating two distinctive narrators: the second person narrator who seems realistic and represents the author's experienced life, and the frame narrator who is considered a fictional character and lives the events of the novel itself.

First, this study will classify the types of voices used in the novel. The underlying argument is that Uzun's use of such voices represents different contrasting social groups and their political stance in the "living world"(Moran, 2012, p. 193).

Although there are other minor types of voices, this section will only focus on significant types that influence the life of the main characters. Utterances are considered in the sense of the speechact theory, which is defined by John L. Austin and elaborated by Etsuko Oishi in which he states that Utterances: "Emphasized the importance of describing the total speech act in the total speech situation in which the language users employ the language: the speaker utters a sentence and performs a speech act to the hearer". (Oishi, 2006, p. 5)

The voices are grouped into four types of utterances. These include oral, factual, religious, and symbolic utterances. These utterances are identified according to the speech act which is defined by John L. Austin as "When we attend to the overall linguistic and situational context including the institutional conditions that govern many uses of language-find that in speaking or writing we perform simultaneously three, and sometimes four, distinguishable kinds of speech acts: (1) we utter a sentence; Austin called this act a 'locution' (2) we refer to an object, and predicate something about the object. (3) We perform an illocutionary act. (4) Often, we also perform a perlocutionary act."(Abrams \& Harpham, 2009, p. 338). After having recognized these groups of utterances, they are identified according to the four types of speech act (I) utterance act; a locution as defined by John R. Searle's regarding Austin's speech-act theory: it "refers to a locution, that is, simply saying something. An utterance act occurs whenever someone says something, regardless of whether or not it makes sense" (Murfing \& Ray, 2003, p. 493). (II) propositional act, which refers to "an object upon which something is predicated (saying something about something else)" (Murfing \& Ray, 2003, p. 493). (III) illocutionary act "the utterance of a statement that performs a particular function (such as ordering, performing, etc.)" (Murfing \& Ray, 2003, p. 493). (IV) Perlocutionary act "an illocutionary act that affects the state of mind and the actions of the person to whom it has been directed" (Murfing \& Ray, 2003, p. 493). The most common type of explicitly expressed voice is oral. The novel begins with a flashback to the rural lifestyle in a Kurdish community where the tradition of oral storytelling was commonly practiced in the past. Perhaps one of the most attention-catching techniques regarding oral narration is Uzun's use of a familiar nursery rhyme to open the novel. Quotation marks are not used to set this rhyme apart, but the narrator explains to readers that the rhyme was narrated to him by his grandmother in the lines immediately following it. Such nursery rhymes are part of Kurdish literature that has been passed down through oral narration.

The nursery rhyme is typographically set apart with a poetic narrative style. The original version of the rhyme reads: a beetle is searching for a husband. When she passes by a group of other animals, they ask, "Beetle, where are you heading?" How they address her makes the beetle angry, so it replies:

Do not call me like that. Address me this way:

Beetle, beetle, lady beetle

With click-clacked high-heels

Impregnating the King with perfume

Where are you heading to?

This traditional nursery rhyme is slightly different in vocabulary among different Kurdish groups residing in different geographical areas. However, the story of the nursery rhyme remains the same. These lines can be found embedded several times in Uzun's novel, although the full story behind the nursery rhyme is never revealed in the novel.

On a textual level, this reference documents an oral tradition that is no longer or rarely circulating among community members. It is recalled and recited by the anonymous protagonist in his mother tongue, Kurdish, which is banned by the state. On a contextual level, the death of this tradition marks the beginning of the death of Kurdish communication between generations. The protagonist does not mention his mother as the narrator of the rhyme, but rather his grandmother. He addresses beetle: "Well beetle, when my grandmother started your story; that is how she began." It is a customary tradition for parents and grandparents to narrate nursery rhymes to their children and grandchildren, but the focus on this recurring pattern in the novel suggests that the author's decision to use this rhyme to open his novel is a powerful allusion to the assimilation process that has influenced the character development of the protagonist. Assimilation as defined by Rebert E. Park and Ernest W. Burgess is

a process of interpenetration and fusion in which persons and groups acquire the memories, sentiments, and attitudes of other persons or groups, and, by sharing their experience and history, are incorporated with them in common cultural life. In so far as assimilation denotes this sharing of tradition, this intimate participation in common experiences, assimilation is central in the historical and cultural processes (Park \& Burgess, 1970, p. 363) 
This demonstrates the loss of communication in the native tongue among three generations: the protagonist, his mother, and his grandmother.

The primary cultural assimilation of Kurds started in the aftermath of WWI. The first phase was when their land was geographically annexed to four other countries. On the internal level inside the countries where Kurds were dominated by the de facto authorities, this phase led to rivalry and instability in the region of the Middle East in general. On the external level, it led to competition between these countries in using all available adaptation tools against all minor ethnic groups residing in the borders of their countries. Even today, almost one hundred years later, acculturation by these countries continues, yet it has failed due to the lack of democratic values in the countries where Kurds have become an integrated part. In Turkey, the focus will be on the internal conflict, which is represented by three generations in the novel.

\subsection{Dormant Identity}

The main character's grandmother, who represents the elderly generation, still communicates in Kurdish. His mother's generation, on the other hand, represents the middle generation. The middle generation here refers to those who had undergone a slow transformation in the middle of the 20th century. The dominant state has intentionally utilized educational institutions and mass media as directories of making other groups of people communicant in their language, and as a result, lose their ability to communicate in their native mother language or at least undermine their mother language skills. The new generation is represented by the protagonist, who struggles for survival in prison after merely trying to get acquainted with his original roots and preserve his culture while facing different phases of assimilation. This generation was given only limited options, either accept the status quo or join the rout of rebellion to liberate what has been lost. So, the opening of the novel reiterates the cultural transformation of an ethnic group that is in the process of being assimilated linguistically as well as literarily.

Another clear example of the loss of communication among the three generations coexisting in the novel is a reference to the famous Kurdish tale Memê Alan(Lescot \& Lescot, 1997). There is an analogy of cultural interruption that is created regarding Bakr, the tale's antagonist nicknamed 'Beko,' who blocks the communication and thwarts the union between Mem, the protagonist, and Zîn, Mem's lover. While in prison, the protagonist of Tu talks about the time he spent with his father, and he mentions how he enjoyed listening to his father singing about the romance of Memê Alan. He then addresses the beetle by telling her: "Beetle, Beko is part of them as well. No, no, they are his descendants...Well, they are the same"(Uzun, 2005, p. 68). The tale of Memê Alan features an unattainable love between two characters who sacrifice everything but do not succeed. The protagonist's love in this novel is his love for his roots and culture, which remains unattainable, likewise.

The second category of utterance is factual references. The notion of factual references here refers to real events or stories embedded in the novel. When there is a period in which certain concepts are created in a specific place, the events taking place usually reflect the spirit of these concepts and the people who made them possible. As a contemporary Kurdish realistic novel that narrates the sociopolitical situation in Turkey from the time it was written, $\mathrm{Tu}$ features factual references that explicitly express what it was like to live within this system. These references are predominant in both the text and context of the novel. For example, the novel refers to the annual Republic Day celebrated in the Turkish state on October 29th each year:
They decorated the public arena of the city with their flags and wanted You to participate in their celebration, as well. They forced children and college students to leave their schools and universities and gather in the public arena... They called out in their celebrations: Congratulations to the great leader! Long live our honorable republic! (2005, p. 20).

The event described above is most likely an apparent reference to the Republic Day, during which the Turkish people traditionally left their houses and had a parade. Historically, when the event takes place, people in Turkey celebrate the Republic Day on October 29. They attend performances and participate in traditional processions with flags and musical bands. For the characters, it does not necessarily represent their reality; instead it was one of the standard assimilation techniques that lasted for more than 60 years in the 20th century. This event was used as an assimilation technique for incorporating minor young ethnic groups into the stat's dominant community.

Another example of a factual reference is an explicit allusion to the Kurdish figure Sei'd Peeran, who fought against the Turkish State for several months in 1925 in order to achieve fundamental rights for his people. As a result, he was captured and then executed. The protagonist mentions Sei'd Peeran to the beetle: "On June 27, 1925, the state set up 51 wooden gallows on the merciful land in front of the Western Gate, and 51 thinkers and leaders of the country were executed, including Sheik Sei'd Peeran" (2005, p. 105). Although the date given in the novel is not identical to the date in historical texts; the later sources declare that he was captured on June 27 and executed on June 30. The protagonist makes a connection between his condition and that of Sei'd Peeran while in prison. This factual reference takes place in the novel as a counter-discourse that has no place in public media outlets. Sei'd Peeran is viewed by the protagonist as an outstanding leader, "Diyarbakir cried. The adjacent neighborhood, the mountains, and the crags cried...The country cried. People cried" (p. 105). While this praise statement in the novel is, without any doubt, considered a crime by the Turkish state, the protagonist proudly narrates this event in his prison cell and continues to say that " 51 young heroes and thinkers of the city were executed on its land"(p. 105).

This line marks the difference between two different political groups: those who protect the state and those who resist the state that denies their existence as a different group culturally, linguistically, and ethnically. It is an apparent reference to the sociopolitical conditions in Turkey at the time the novel was written. During that time, forbidding minor ethnic groups' freedom of expression was a common legalized right practiced by the dominant group. Therefore, the writer could not publish this novel in Turkey in 1985, and instead, he published it first during his exile in Sweden.

There are also two types of religious utterances in the novel. One is directly expressed by the protagonist's mother when the narrator recalls how she used to narrate some of the prophet's teachings to her son. These kinds of discourses function as common Islamic instructional guidelines and appear throughout the novel. The other religious references are made by the guardians of the nation-state and function as an intimidation tool. They are presented in a way that can be considered as counterreligious statements if religion is meant to save human beings instead of inflicting pain on them.

Traditionally, the primary sources of education for Muslim Kurds were religious texts, including the writings of the prophet Muhammad himself. This education process usually began by teaching the Arabic alphabet to children aged between five and ten. This has been documented by the majority of classic Kurdish writers such as Jizeeri, Khani, Taha Ma'iy, and Sadiq Biha'din. 
A reference is made to this education at the very beginning of the novel. The narrator tells readers how often his mother would very kindly talk to her son about the importance of religion, and then start narrating the prophet's teachings "My black-eyed boy, would you like me to come in and read you some passages of his Excellency, the messenger? ... 'The beauty of Man lies in the beauty of his tongue. Paradise lies at the feet of mothers"' (Uzun, 2005, p. 26).

By uttering such passages, his mother's intention is to give religious and moral lessons to her son. The generation gap once again plays an essential role in this passage and how these religious references are interpreted to become more explicit. The middle generation, represented by the unnamed character's mother, uses these religious passages to guide their loved ones away from the dangerous world of politics and direct them towards the peaceful world of religion to help them to become more valuable humans. However unclear the new generation's place may be, it both understands how to accept and respect pious people on the one hand, while on the other hand, the protagonist that represents this generation does not use any derogatory terms that may assign characteristics of Islamophobia or Theophobia in the novel.

This duality is explicit in how the main character replies to his mother when she knocks at his door to narrate some of the prophet's passages to her son. "How would you have replied to respect her and win her over? 'Why not, my dear Mom, please,' you replied" (Uzun, 2005, p. 26). This is fundamental regarding the character's attitude in belonging to a modern, stateless nation compared to how the nation-state guardians have used such religious utterances. As for the nation-state, such texts serve a specific purpose.

A significant difference between the attitudes of the citizens in the nation-state and a stateless nation lies in how controversially religious references are being used. Religion is used in a stateless nation to provide instructional guidelines for leading the community. In this novel, for the nation-state, religion is used to display dominance and execute intimidation. In the novel, the state-appointed guards have named the torture cell "paradise" This is seen when a guard calls for the prisoners' attention "You are now in paradise. The name of this place is paradise. You will see what we are going to do to you" (Uzun, 2005, p. 182). In the modern era of nation-states, this kind of treatment represents how the concept of statehood has replaced religion for the dominant ethnic group. Thus, everything regarding religious symbols falls under the control of the state.

When language fails to function correctly, symbolic references compensate for the loss of communication. In this novel, symbols are used as a means of indirect expression, as described by Anges Petocz: "We find treatments of the symbol as vehicles of indirect expression" (Petocz, 1999, p. 12). The symbols in this novel, such as the beetle or the city citadel, relate to the local setting of the novel itself and more specifically to the location where these symbols are identified. In this case, both the symbols of the citadel and that of the beetle have heteroglossic meanings. One of the commonly used animals in Kurdish oral literature is the beetle. In this novel, the symbol of the beetle has both allegorical and satirical meanings.

The first meaning is found in oral stories and narrated to the protagonist by his grandmother. It is allegorically found in the context rather than the text and represents man's search for home or shelter in Kurdish Literature. Meanwhile, in the text of the novel, the beetle is satirically used to represent a listener. The protagonist, having been ignored by both the civil and the military judges, has a one-sided conversation with a beetle he finds in his prison cell. This conversation addressed to the actual beetle, and symbolic beetle brings to light the restriction and political corruption of the system.

Diyarbakir Citadel is ironically used and has a dual representation, as well. At the beginning of the novel, it is said that this city site (now Diyarbakir) was a place where people with many differences used to fight each other. However, they later united and agreed to fortify themselves against external forces. They decided to build a citadel where they could all live peacefully. While the citadel represents fortification against external forces, in the novel, it is used as a torture cell to hold local native prisoners and silence any voices that differ from the state's dominant voice. Its prisoners are the descendants of those who, at one point in history, ended the war for the sake of coexistence and first built the citadel. Therefore, the citadel in the novel is an ironic symbol used to represent oppression committed by the government.

Ultimately, the combination and presentation of factual, oral, religious, and symbolic utterances in $\mathrm{Tu}$ are considered a significant contribution by Mehmed Uzun to the Kurdish novel precisely and a characteristic of a modern novel in general. Embedding more than one genre within a single novel is a crucial feature only found in modern novels, and $\mathrm{Tu}$ is an excellent example of this. The main character is anonymous because as a member of an ethnic group living in Turkey, he represents a nation as a whole that is undergoing the harsh experience of being socially, ideologically, educationally and politically restricted. Thus, by grouping a variety of voices into a single whole, the author succeeds in expressing the extreme aspects of Turkish modernity.

\section{Polyphonic aspects of Uzun's Initial Novels.}

In The Problems of Dostoevsky's Poetics, Mikhail Bakhtin, who is considered the founder of the concept of polyphony in the novel, asserts that the most critical aspect of polyphony is "in the fact that the voices remain independent" (Liisa Steinby, 2014, p. 42 ) and those voices represent a higher version of unity "than in homophony" (Liisa Steinby, 2014, p. 42). Bakhtin defines polyphony as the representation of infinite dialogue in the novel without reducing such a dialogue to final closure. The characters are not dominated by the author to represent his subjective view, but they are given independent voices who represent real-life. Opposite to authorial context, characters have their voices, and the truth is expressed through the diversity of consciousnesses. For Bakhtin, this is true in Dostoevsky's novels because no central character dominates almost everything in the novel. In the light of Mikhail Bakhtin's definition, what follows is a highlight of the polyphonic aspects of Tu as the context of this novel, and the timeframe it was written is seen as an appropriate subject matter due to the censorship of the Kurdish language in the Author's country of birth.

Prison is the most noticeable setting in this novel where polyphony takes place. The title of the novel itself, Tu, is translated into 'You' - a dialogic form. Narrators belong to two different groups who are informed by one another; the firstperson narrator gets informed by the second-person narrator. The dialogue takes place in the prison between various characters, which are interconnected to each other in the prison cells, in the form of flashbacks and real-time. Actions and ideas have been preserved and affirmed in the novel without being affected by the authorial tone.

The title comes in the form of an addressee $\mathrm{Tu}$ (You) which involves a speaker and a listener. Explicitly, it brings to the foreground one part of the narration, which is the second person narrator. Implicitly, it informs the readers about the existence of the otherness in the novel. This otherness consists of parallel 
voices sharing some aspects of equality. This title does not give any hints about the sense of completion in the novel. It leaves a gap in the novel, opening up space for readers' subjective viewpoints to take place rather than creating a direct relationship between author and reader via a dominant authorial persona. In most cases, the dominant authorial persona is considered as a direct obstruction by the author himself.

A political allegory becomes apparent as the events unfold. "Now you cannot go anywhere; I will not let you. You are my guest. Your departure is within the story. Now you are here, neither my grandmother nor my mom, not even the garden or games or streets, and the entertainment is gone as well. We are here now alone, with no one and no way out. Alone in this confinement. They captured us and put us here, locked us behind seven iron gates, and chained us with handcuffs" (Uzun, 2005, p. 11). Since the main character is in prison now, it is the censorship of freedom of expression in public that pushes him to speak to an insect in prison. This beetle, which only receives but is incapable of responding, allegorically represents the unnamed character who is, according to the state policy, supposed to be a means of reception rather than a means of representing himself. In the world of the novel, this is true about the main character; he was confined and could not defend himself against the accusations made against him that include holding a few books in his mother tongue.

The main character is considered a narratee when the second person point of view takes place. There is a contradiction between both viewpoints. Although the second-person narrator is omniscient, he cannot take any actions to change the course of the events in the future. While the first-person narrator, however having limited knowledge about the future, is more capable of planning and undertaking actions to change the future because he is a character in the novel and is indirectly informed by the second-person narrator, such as in the following instance when he hid the banned books so as to avoid being captured.

Shortly before that night, while having the list of banned books in your hand, you checked all your books one by one. You put aside banned ones and all Kurdish books and magazines, and you put the rest in their places. (Uzun, 2005, p. 15)

The contrast lies in details provided by narrators. The second person narrator does not usually comment on the details; instead, he merely tells the story of the novel, while it is the task of the first-person narrator to comment on the details about the juxtaposition of brutal reality and the beauty that's embedded by the city.

Beetle, Diyarbakir is surprising, very surprising...it is the city of dreams. It has everything, ancient and modern, virtue and vice, enjoyment and boredom, humanity and barbarism, activities and tardiness. Love and egoism, happiness and sadness, sympathy and striking, and everything, it embodies everything. Its people are like that as well, authentic and foreigners. (Uzun, 2005, p. 103)

The above is an example of how the unnamed character views the city of Diyarbakir, the primary setting of the novel, by uttering a contradictory statement like the contradiction in the narrative form of the novel itself; he confirms the existence of odd forces without giving a finalized concluding statement. However, he plans for his future by trying to get engaged in conversation with the rest of the characters. He starts jotting down different events, oral short stories, and even how the prison system works for the time being so that the future generation can get acquainted with such circumstances. In the following introductory remarks, the unnamed character uses the flash-forward technique to inform his readers about what he has been through.

Once upon a time
Peace be upon the poor kids of those days

Damn and curse be upon Satan and hypocrites of those days

Not me, the poor of those days have lived this story. (pp. 59-60)

The author has succeeded in creating a discourse where fictional and real stories are mixed and take place side by side by choosing two different narrative perspectives.

Another important polyphonic element of Uzun's novel Tu is the dialogic nature of the discourse. The prisoners come to an agreement to work with each other, educate one another, and appoint a prisoner as a guard at night (What evidence from the novel can you present to explain why there needed to be a guard at night? How did the prisoners educate one another?). In this sense, they are realists who have built a typical system for themselves to abide by daily, and yet idealists when they put to practice their knowledge and learn from one another. Avoiding the monologic discourse, Uzun has adopted the technique of multi-voices, which in turn has made his novel more vibrant and livelier regarding the development of characters. (Can you give an example of this from the novel? A place where the livelier, more vibrant presentation would have been dulled if written without multi-voices?)When it comes to a single character, Bakhtin states "A single person, remaining alone with himself, cannot make ends meet even in the deepest and most intimate spheres of his own spiritual life; he cannot manage without another consciousness" (Gary Morson, 1990, p. 469). This statement is very much right about Uzun when he creates an alternative consciousness, which is a symbolic beetle, yet it served his cause for providing a listener to the unnamed character. In order for the dialogism to function appropriately, the author has created two dialogic concepts in his novel. Firstly, Tu's unnamed character is accompanied by unresponsive beetle. He talks with this symbolic beetle in the form of dialogue. This beetle is the center of attraction in prison and his flashbacks as well, especially when he brings forward his childhood memories where his grandmother used to narrate stories of animals to him. Secondly, the existence of contradictory voices makes Uzun's dialogism an appropriate pattern that enables characters to contradict, react, and take actions.

Such contrasting voices have been embedded in the novel in which they often contradict each other. This is another point featuring one of the elements of polyphonic novel: this point is argued by Steinby, Liisa, Klapuri, and Tintti who suggest that "The idea of polyphony implies not only to a plurality of voices, but also a genuine encounter among the various subjective points of view" (Liisa Steinby, 2014, p. 40). The subjective perspectives, contradicting each other, are essential in establishing the authenticity of polyphony. Tu consists of voices that have been confined in a specific region, including the dominant voices of guards and detectives, subdominant voices of prisoners, the oppressed voice of an instructor, and a female prisoner. According to the civil court and state law, these characters share common crimes, such as the quest for identity, freedom of expression, and writing in their mother language.

All the characters, captured by the state, represent the cause of a minority ethnic group whose members are struggling through different generations to preserve their natural rights. Apo, the eldest prisoner, is now learning Turkish with the help of a Turkish instructor who has been imprisoned for having published a couple of research papers about the Kurdish nation. He represents the elderly generation who, beyond their mother tongue, could not speak any other languages, and the Turkish instructor is learning Kurdish with him at the same time. The unnamed character represents the hybrid generation who speaks at least two languages or more due to the socio-political background he was 
raised in. As put by Homi Bhabha in his book titled The Location of Culture:

Hybridity is the revaluation of the assumption of colonial identity through the repetition of discriminatory identity effects. It displays the necessary deformation and displacement of all sites of discrimination and domination. It unsettles the mimetic or narcissistic demands of colonial power but replicates its identifications in strategies of subversion that turn the gaze of the discriminated back upon the eye of power. (Bhabha, 2004, p. 112).

It is these discriminatory actions taken by the dominant group that has led to the awakening of consciousness in members of other ethnic groups that led them to question their authentic identity.

\section{Genuine Polyphony Versus Problematic Polyphony}

When dealing with a literary text by using the formalistic literary approach, it is possible to either find a genuine polyphony or a weaker form of polyphony: a problematic polyphony. In the case of having certain polyphonic elements in a text such as a dialogism, parallel voices, lack of a central hero, and unfinalizability, this usually leads to genuine polyphony. However, sometimes a weaker form of polyphony could be found, probably when some of the elements as mentioned earlier do not exist in the target text. A problematic polyphony takes place when a literary work is analyzed by excluding the application of formalism, at which a web of connection takes place, and that is where the authorial interference is approved. As a result, polyphony becomes problematic because there exist certain polyphonic elements in the text that cannot be denied when other literary approaches are applied, as it is the case of certain aspects of Mehmed Uzun's Tu with the characters' discourse, the dialogic nature of the title, and the unfinished ending.

When the labyrinth is created concerning the authorial epilogue, the novel could have only one authorial narrator; he is the one who sometimes becomes a second-person narrator, while other times he is the narratee and the first-person narrator: the unnamed character in Uzun's Tu, for instance. When having a look at the author's biography, this labyrinth becomes more clear and valid in reflecting author's life as he states in the epilogue "In March 1971, I myself and few friends were captured altogether. For almost two years, I was detained in the military jail of Diyarbakir and Ankara. It was a great experience for me being in Diyarbakir jail; it was a school"'(p. 222). Excluding formalism, this personal incident makes interference very clear if the novel is approached from any other literary approaches. The life of the unnamed character and the rest of the characters in jail, including state guardians, could realistically reflect the events that have influenced the author himself. For instance, in an article titled Diyarbakir: The Slap in the Face, the author states,

"my life has been marked by two things: suffering and the lie. And one can say that whatever my faults, the forty-seven years of my life have been entirely devoted to a struggle designed to free me from these two evils. I have incessantly forced myself to decipher the hideous, primitive, and cruel countenance of the lie, seeking to create on the basis of suffering artistic works placed at the service of mankind, of humanity as a whole" (Uzun, 2003, p. 25).

The other element that continues to become a valid polyphonic aspect of the novel in the light of other literary approaches is the dialogic nature of the title. From the sense of how the word Tu (You) is being used, foregrounding one of the narrators of the novel, and then confirming the existence of otherness. Consciousness as an addressee, whose real identity is not clarified in Tu but as a character, he is identified as a first-person narrator and sometimes as a narratee when he is addressed by the secondperson narrator.

The lack of a central hero and the unfinalized ending of the novel do not ultimately give a final objective conclusion to the readers. There is an unstable state system which does not function properly in the text; it failed in promoting equality among people and preserving their rights, mainly, the individual rights of minorities. This is represented by a group of people who have been jailed through incarceration campaigns because of their political stance, language, national or ethnic origin, and those who have rejected different means of assimilation which will jeopardize their cultural values. Provided that they have violated the law, this group, mainly consisting of minorities, are now facing imprisonment on varying terms.

Some prisoners believe in coexistence, without resorting necessarily to other means of resistance, and have agreed to share cultural values and use such means to educate one another. Such is the case with the psychologist, who has worked in the Kurdish community and as a result, was detained. They are neither given freedom to do so in jail, nor were they equipped with required resources to survive in such circumstances. That is the moment where the novel openly ends, without giving a clear indication of what such efforts might bring. This unresolved ending is another essential aspect of the polyphonic novel, which was emphasized by Bakhtin in Speech Genres:

There is neither a first nor the last word, and there are no limits to the dialogic context (it extends into the boundless past and boundless future). Even past meanings that is those born in the dialogue of past centuries can never be stable (finalized, ended once and for all) - they will always change (be renewed) in the process of subsequent, future development of the dialogue. (1986, p. 170).

As a result, Tu is analyzed in more than one literary approach to proving that other types of polyphony, problematic or partial polyphony, can be achieved when other approaches are applied that has been established in the second half late period of modernism.

\section{Uzun's Diasporic Fiction in Identity Formation}

Mehmed Uzun considered writing his first novel after he was released from prison. However, he did not start writing until he realized that the Kurdish conflict in Turkey is multifaceted. These include the lack of political activities and organizational structure as well as social, cultural, intellectual, literary, philosophical, and psychological problems. These problems are often considered representative themes in most of his writings. In Tu, as well as Mirina Kalekî Rind, Uzun's main characters continuously search for cultural elements that have been lost either because they are prohibited or because the dominant government has assimilated those who practice them.

This part of the study will demonstrate how New Historicism sheds light on Uzun's contribution to the timeframe in which the novels were written and to modern Kurdish novels. It is considered that New Historicism is the appropriate literary approach to emerge the sense of otherness in Uzun's narrative and to encounter the main narrative that's already established. In the epilogue of Tu, Uzun states that this novel has embedded specific excerpts from Kurdish books and magazines that have been lost, which indicates that he intentionally used these sources for the sake of preservation rather than for reference and marks the fact that Uzun was writing during a time of extreme censorship. Uzun was born in a country where he could not transform authentic oral voices into a formal written language; he was not allowed to write in his mother language as he indicated in the epilogue of Tu, "my life in prison has become the essential element of writing this 
novel ... I understood that I was not writing a novel, but rather, I was writing a report, an event, a memoir" (Uzun, 2005, p. 224). As a result, he was forced to escape to another countrySweden - to have this right.

Uzun's novel Tu established a place for him in New Historicism and served to foreground the voices that have been traditionally persecuted or restricted under the harsh circumstances imposed by the dominant groups in power. In order to evaluate Uzun's use of historicity in this novel, under consideration is the definition of New Historicism in which New historicists "acknowledge the importance of the literary text, but they also analyze the text with an eye to history. In this respect, the new historicism is not 'new'; the majority of critics between 1920 and 1950 focused on a work's historical content and based their interpretations on the interplay between the text and historical contexts (such as the author's life or intentions in writing the work)" (Murfing \& Ray, 2003, p. 194). Also, three concluding remarks are considered by Anton Keas, who gives a necessary elaboration to the status of New Historicism. The term has been broadly studied by various groups of critics after it was initially coined by Stephen Greenblatt.

In his study, New Historicism: Writing Literary History in the Postmodern Era, Anton Keas concludes with three essential points that animate literary texts more than their predecessor: traditional Historicism. First, he states that New Historicism extends the limitation previously set by traditional Historicism: its Interdisciplinary orientation embraces textual and symbolic representations that include literary and nonliterary documents as well as paintings, films, photographs, monuments, rituals, everyday myths, customs, and symbolic activities (Kaes, 1992, p. 156).

In his novel, Mirina Kalekî Rind, the author takes advantage of a traditional lifestyle, notebooks, the name of cities where the main character's articles have been published, and most importantly, his allusion to the authors considered as necessary in the perspective of the novelist. In a long paragraph, the author writes: Now, besides my flower, one of your belongings is also available among the old books. Close to the flower that had passed through many borders, and even when I met you, it was in my pocket. The reception is now warmer than before. In a foreign country, I overlooked the flower, home, the box, and my surroundings. I looked at them for many hours. (Uzun, 2007, pp. 115-116).

The items used here are all used in a symbolic sense. They become part of the character's life abroad. These items help him make sense of his life and connect him to his surroundings. On the contextual level, it is through specific meetings with an old man, that the main character becomes capable of creating an inquisitive mind to search and develop answers for his question related to a question addressed to him by the old man. The question is related to nice people: who are they? Where can they be found? Moreover, what is their task?

Second, as Kaes states in his article titled New Historicism: Writing Literary History in the Postmodern analyzes New historicism as the

circulation of representations both inside and outside the domain of literature and its magnitude - in the community as well as the textual dimension: How are power, poverty, crime, the penal system, and war represented and discursively constituted at a particular place, at a certain time? ...How does the intertwining between mass culture and politics affect the political process? New Historicism is concerned with analyzing the complex routes by which culture, society, and political life crisscross and intersect (Kaes, 1992, p. 156).

In terms of how wars have affected the character's life, after a long journey in self-development and language learning, the Old
Man in Uzun's novel represents the unrepresented voices in the war-torn cities. Besides being an educated figure, having contributed to several newspapers, written unpublished notebooks of memoir, he has chosen to escape from the savagery of politics that is being practiced in cities and lives in a little village. The narrator gives details regarding the Old Man's skills in terms of language skills and his original places and the cities he visited:

The Old Man was from Diyarbakir. He was born there and was raised there. He studied language and literature in Istanbul and Cairo. He knew Arabic, Persian, and Turkish very well, and he was well acquainted with their literature. After his study in Istanbul and Cairo, he went to Baghdad and remained there for a while, ... he has closely seen both world wars. (Uzun, 2007, pp. 97-98).

The narrator has given details regarding the Old Man's education and his experience in other countries. The Old Man has chosen to live in a small village which gives him comfort and not a big city that has assassinated humanity in the Old Man's perspective. He says, "Justice, honor, and liberty has been assassinated in the foreign external world" (Uzun, 2007, p. 98). As a result, he has been disappointed regarding the external world and has chosen to isolate himself from the external world.

Third, it stresses "the contingent and conditional, the nonsystematic, contradictory, and even coincidental. It abhors large-scale, totalizing claims, and instead pursues 'local knowledge"' (Kaes, 1992, p. 156).

The focus is on the creative imagination that allowed Uzun to bring two aspects of his protagonist's life to the foreground: his past life through flashbacks and the events taking place in the world of the novel that reflect the real historical events in Turkey. This broken style intentionally reflects the broken sociopolitical system of the country in which it takes place. This is also clearly represented by the narration style of Uzun's initial novels.

VI. Narrator, Narratee, and the Representation of New Historicism

The narrative style of Mehmed Uzun's novel Tu is divided into two parts. The first chapter is narrated by an anonymous character who becomes the novel's protagonist. Every odd chapter is then narrated by the same character: the frame narrator. Every even chapter is narrated by a second-person narrator who stands outside the world of the novel. Based on the setting of the novel, the historical events at the time, and the author's notes published as an epilogue, one can relate some elements of the novel to the author's real-life experiences at the time of writing the novel. Since the voices of major characters are representative of their own life experiences, the analysis will begin with the novel's unnamed protagonist.

The anonymous protagonist, although fictional, shares some of Uzun's real experiences in Turkey. In the novel, both narrators narrate the story of a character who has been imprisoned without having committed any apparent crimes against the state. On the other hand, the court also does not have any reasonable evidence for having imprisoned him. In reality, the author himself was captured by the Turkish state in March 1971. Uzun once stated that "after having been released from prison, I had the urge to write down those events and that experience ... In the middle of 1981, I started writing the novel" (Tu, pp. 222-223). This assertion by the author himself is sound proof that he shared some of his personal experiences through the means of his novel. Accordingly, the second person narrator could be a real person reporting about what he has been through. As a result, the second person narrator of the novel is considered as a reliable narrator who can be trusted in narrating the events of the novel. 
The protagonist of $\mathrm{Tu}$ is not the only character with a resemblance to a real historical figure. In the novel, Apo, an elderly prison representative, does not speak Turkish and is trying to learn it from a Turkish sociologist who was detained for having published two books about Kurds. Apo is 73 years old and has spent most of his life-fighting in wars. Apo may represent Halil Chiftchi, who, according to Uzun's epilogue to the novel, "was in Diyarbakir prison because of the claim that he was a member of Kurdistan Democratic Party" (p. 231). The protagonist's cousin, unnamed as well, in the text was also detained for five years and was assassinated six years later. He welcomed the main character to prison, introduced the prison to him, and helped him find a bed and clothing until the protagonist's items arrived. He primarily serves to instruct and guide the main character in prison. In reality, he represents the author's cousin, Fereed Uzun. "He was an active, well-informed person" (p. 231). Meanwhile, the sociologist, who is described in the novel as a Turkish writer expelled from university for having written two books about Kurds, is in reality "Ismaeel Beshikchi, a well-known Turkish intellectual and researcher in Turkey who writes about minorities in Turkey and primarily focuses on the Kurdish community.

Having established the labyrinth between the fictional and the real, this study finds it relevant to develop an eclectic approach in analyzing Uzun's novel. It is noted that factual fiction, due to the circumstances Kurds live in, is the most dominant novel genre among established novelists whose language is inaccessible to the academic scholars and journals publishing majorly in the English language.

\section{Concluding Remarks}

The entire representation of utterances, characters, and setting leads to the production of a realistic novel with the consistent discourse that may be considered an objective view of a specific time in history, which is undermined. While the novel is fictional, it nevertheless depicts the reality of the people. It captures the state's treatment of its constituents and narrates the system at the time. Uzun's novel also expresses the social life of the Kurdish people in the form of flashbacks. Tu is a medium of transferring cultural values that may not otherwise be expressed due to the ban on the Kurdish language and restrictions imposed on the country's minor ethnicities. It is, therefore, not an interpretative reading by the author, but a mirror held up to the attainable state of affairs of both political and social life.

For Mehmed Uzun, a novel is the privileged literary genre that mixes aspects of real-life with imaginative fictional prose. In the epilogue, he states, "There are novelistic principles and restrictions. One could talk about imagination and dreams, as well as factual aspects of life and society. That is how it is" (Uzun, 2005 , p. 224). Therefore, according to Uzun, a novel must combine factual events, stories, and aspects of real-life with creative imagination. His use of the beetle character as both a listener and as a reference to traditional oral stories in all uneven chapters is evidence of this. Uzun suggests that beetle brought these ideas and thoughts to light. In my viewpoint, if these chapters did not exist, "this would not have been a novel" (Uzun, 2005, p. 224).
Consequently, this ending results in a polyphonic novel in the light of both formalism and New Historicism, providing that such an ending remains open for discussion even when there exists a powerful connection between the persona of the novel and the author's biography. The unresolved ending continues to become one crucial element of Tu as a polyphonic novel.

Additionally, it can be inferred from the existence of certain polyphonic elements, such as the parallel voices of the novel, the lack of central hero, and the dialogic nature of the characters in Mehmed Uzun's Tu, that there exists a problematic polyphony which cannot be denied entirely even if other literary approaches are applied, but the use of such approaches may make some elements invalid, specifically the freedom given to the characters in the world of the novel and the relationship between narrators of the novel.

Mehmed Uzun's initial novels preserve several voices in various passages that demonstrate fictional reality, assimilation, and suppression of minorities. Uzun's novel reflects the silenced voices and allows these voices to survive alongside the dominant narrative in the media and educational institutions. The lack of authorial control is intentionally oriented throughout the novel so that every subjective voice can be heard on the same level.

\section{References}

Abrams, M. H., \& Harpham, G. G. (2009). A glossary of literary terms (9th ed.). Boston: Wadsworth Cengage Learning.

Bakhtin, M. (1986). Speech Genres and Other Late Essays (V. W. McGee, Trans.). Austin, TX, United States: University of Texas Press.

Bhabha, H. K. (2004). The location of culture. London ; New York: Routledge.

Gary Saul Morson, C. E. (1990). Mikhail Bakhtin: Creation of a Prosaics. Stanford: Stanford University Press.

Kaes, A. (1992). New Historicism: Writing Literary History in the Postmodern Era. Monatshefte, 84(2), 148-158.

Lescot, R., \& Lescot, R. (1997). Memê Alan : destana Kurdî. Beyoğlu, İstanbul: Avesta.

Liisa Steinby, T. K. (2014). Bakhtin and his Others: (Inter)subjectivity, Chronotope, Dialogism: Anthem Press.

Moran, D. (2012). Husserl's crisis of the european sciences and transcendental phenomenology : an introduction. Cambridge England ; New York: Cambridge University Press.

Murfing, R., \& Ray, S. M. (2003). The Bedford Glossary of Critical and Literary Terms. New York: Bedford/St. Martin's.

Oishi, E. (2006). Austin's Speech Act Theory and the Speech Situation. Esercizi Filosofici, 1, 1-14.

Park, R. E., \& Burgess, E. W. (1970). Introduction to the science of sociology, including an index to basic sociological concepts (Student ed.). Chicago,: University of Chicago Press.

Petocz, A. (1999). Freud, Psychoanalysis, and Symoblism: Cambridge Universiy Press.

Uzun, M. (2003). Diyarbakir: The Slap in the face. The International Journal of Kurdish Studies, 17(2), 25.

Uzun, M. (2005). Tu. Istanbul, Turkey: Ithaki.

Uzun, M. (2007). Mirina kalekî rind (1. baskı. ed.). Kadıköy, İstanbul: İthaki. 


\section{محهمهد نئوزون وهكو نينهريَ ثهكيّرِانا كوردى يا نوى}

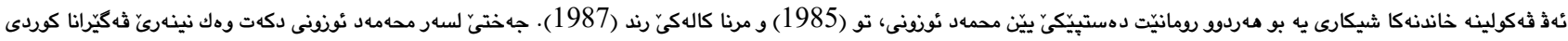

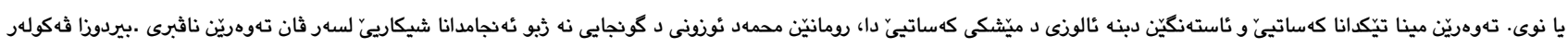

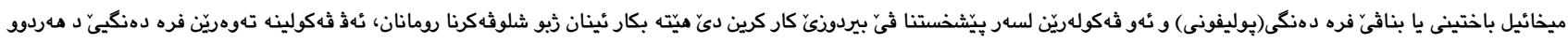

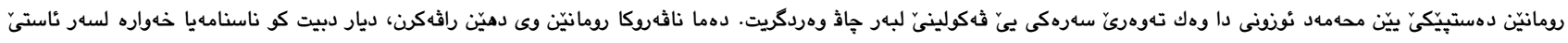

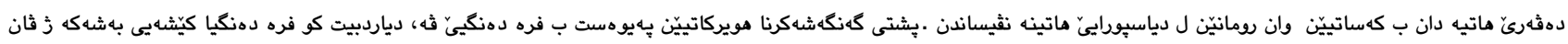

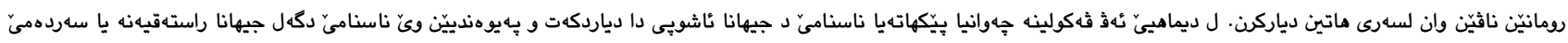

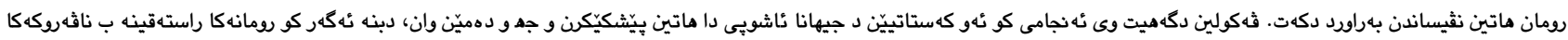

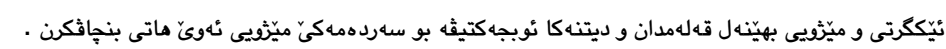

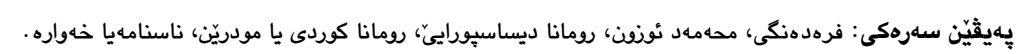

\section{محمد أوزون كممثل للرواية الكردية الحديثة}

هذا البحث مخصص لتحليل اثنين من الروايات الأولية لمحمد أوزنون (تو (1985) و مرنا كالةكيَ رند .(1987) البحث يركز على محمد أوزنون كممثل للرواية الكردية الحديثة. فيما يخص بمفاهيم

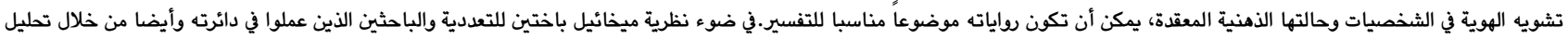

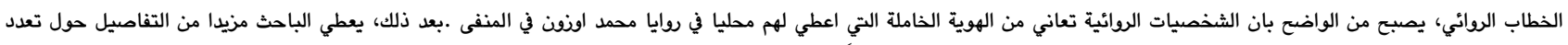

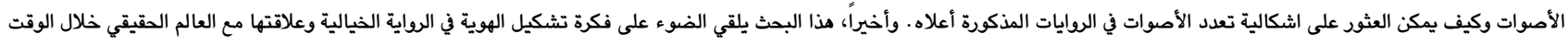

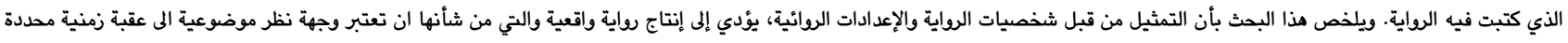
في التاريخ التي قوضت. الكلمات الدالة: تعدد الأصوات، محمد أونون، رواية المنفى، الرواية الكردية الحديثة، الهوية الخاملة . 